\title{
Use of dietary fibre concentrates in semi-finished biscuits technology
}

\section{Olena Kobets, Oksana Arpul, Viktor Dotsenko, Iryna Dovgun}

\author{
National University of Food Technologies, Kyiv, Ukraine
}

Keywords:

Flour

Emulsifier

Gluten

Fibre

\section{Article history:}

Received 29.08.2016

Received in revised form 26.11.2016

Accepted 30.12.2016

Corresponding author:

Olena Kobets

E-mail:

Elenka021991@,

ukr.net

DOI: $10.24263 / 2310$

1008-2016-4-2-3

\section{Abstract}

Introduction. The effect of the dietary fibre concentrates, namely, wheat, cocoa and apple fibres on the protein-proteinase and carbohydrate-amylase complexes of wheat flour is studied.

Materials and methods. The study of the influence of dietary fibres on the quality indicators of dough gluten was conducted using conventional methods, and structural-andmechanical properties - with the help of alveograph, amylograph and farinograph.

Results and discussion. The presence of fibre promotes an increase of water-absorbing capacity and time of the dough formation and reduce its stability. It is established that fibre increases a degree of water binding by the dough on average by $12.5-23.2 \%$, due to the ability of its polysaccharide complex to bind and retain water. The results of the study on alveograph indicate that the introduction of fibre in the amount of $15-25 \%$ by weight of flour compared to the control increases the dough elasticity by 1,2-2 times and reduces its extensibility by $1.3-3$ times. The necessity of the use of surface-active surfactants in the technology of semi-finished biscuits to improve the quality of the finished products is proved. It is determined that the introduction of a mixture of the emulsifiers "Grindsted Cake» with fibre into the dough increases its extensibility on average by $2.6 \%$ and elasticity by $2.6-6.8 \%$, which will obviously have a positive impact on the quality of the finished products.

Conclusion. Adding a mixture of the emulsifiers «Grindsted Cake» leads to increased porosity, specific volume and lifting coefficient of the finished products with the addition of wheat fibre, apple fibre and cocoa fibre, thus allowing to bring the quality indicators of the semi-finished products to that of a control or surpass them.

\footnotetext{
$1008-2016-4-2-3$
} 


\section{Introduction}

Human health is determined by its nutritional status, which is a degree of providing the body with required essential substances and energy. Health can only be preserved if there is a full satisfaction of physiological needs of energy and food nutrients. Human diet should meet modern concepts of nutrition science whose requirements should be considered when developing the strategic development of the food industry [1].

Unfortunately, diet imbalance is growing in Ukraine with every year - deficiency in proteins, vitamins, macro- and microelements and other biologically active substances, which leads to the weakening of the immune system, increasing the number of chronic noncommunicable diseases. This indicates the need to develop food products of functional purpose, which will consist of essential substances for the human body [2, 3].

Analysis of literature data and problem statement. Recently, scientists have been paying great attention to the enrichment of the diet of the population with dietary fibres (DF), which are a complex of biopolymers containing polysaccharides (cellulose, hemicellulose, pectin) as well as lignin and its associated proteins that form the cell walls of the plants. The structure of these substances and their intermolecular interactions determine the properties of DF, including the ability to retain moisture, ion exchange, and other properties, the behaviour in the technological and culinary processing, impact on quality of food [4].

The deficit of DF in human nutrition is one of the main risk factors for various diseases: dyskinesia of colon with constipation, irritable bowel syndrome, colon cancer and rectal cancer, atherosclerosis, metabolic syndrome, obesity, type 2 diabetes, hemorrhoids, varicose veins of lower extremities, etc. [5].

DF have a wide range of effects on the human body. They stimulate intestine peristalsis and regulate its motor function; reduce the absorption of cholesterol and fatty acids; adsorb intestinal toxic products, alien substances, carcinogens, radionuclides, and some proteins, fats and carbohydrates; stimulate the processes of secretion of bile, prevent its absorption and normalize the function of bile ducts; create a sense of satiety and reduce energy consumption; form and increase stool, thinning intestine contents; promote the rapid excretion of products of incomplete digestion of food substances (toxins); slow the rate of absorption of glucose, which reduces the need for insulin; increase the sensitivity of tissue receptors for insulin and tolerance to carbohydrates; positively affect the intestinal microflora; accelerate the process of fat metabolism in the body $[6,7]$.

Deterioration of the environmental conditions and food quality require that scientists and manufacturers develop new food products with functional properties. That is why the enrichment of flour confectionery products (FCP) with DF is an urgent problem.

The research conducted previously established reasonability of the enrichment of FCP, namely semi-finished biscuits and cakes, with the concentrates of DF - wheat fibre (WF), apple fibre (AF) and cocoa fibre (CF) containing 65-95\% DF. It was determined that optimal dosage of the fibre to the mass of the top-grade flour is $20 \%$ that reflects a decrease of organoleptic characteristics in case of dosage exceeding.

The purpose and objectives of research. The purpose of the research was to determine the effect of the concentrates of DF - WF, AF and CF on the quality of gluten and structural-and-mechanical properties of dough and finished products.

The objective of the work was to study the changes of the quality of gluten, proteinproteinase and carbohydrate-amylase complexes of biscuit dough when adding DF to it and determine their impact on structural-and-mechanical properties of the quality of the finished product. 


\section{Materials and methods}

The objective of the research is concentrates of DF - wheat fibre, apple fibre and cocoa fibre produced by Microstructure (Poland), which contain $65 . .95 \%$ of DF, and their impact on the quality of the dough. Fiber was added to the mass of top-grade wheat flour in an amount of 15,20 and $25 \%$.

The influence of DF on the quality of dough gluten was conducted by the conventional methods [8]. Structural-and-mechanical properties of the dough quality were determined with the help of alveograph, amylograph and farinograph [9].

The porosity of the finished products and specific volume were determined by the scanned images made in the photo lab using Canon iR1210 copier at the highest contrast and with further using the program Microsoft Excel [10]. The baking loss was measured by the difference in mass of the dough piece before and after baking.

The coefficient of product lifting was determined by the ratio of the height of the finished product to the height of the dough piece under conditions of pouring the dough of equal weight to identical forms.

\section{Results and discussion}

The need to study the impact of fibre on the content and quality indicators of gluten is caused by the peculiarities of its chemical composition, high degree of its dispersion. It is possible that high dispersion of the product leads not only to changes in the quantitative and qualitative content of its individual components, enzyme activity, degree of assimilation, but also to changes of its influence on the dough biopolymers.

The technology of biscuit products permits the use of wheat flour with low gluten. Otherwise, semi-finished products will have a small volume and low porosity. The impact of WF, AF and CF on the quantity and quality of dough gluten is shown in Table 1.

Fibre impact on the gluten quality indicators

Table 1

\begin{tabular}{|c|c|c|c|c|c|c|}
\hline \multirow[b]{2}{*}{$\begin{array}{l}\text { Dough } \\
\text { samples }\end{array}$} & \multirow{2}{*}{$\begin{array}{c}\text { Replacement } \\
\text { of dough } \\
\text { with fibre, } \\
\%\end{array}$} & \multirow{2}{*}{$\begin{array}{c}\text { Wet } \\
\text { gluten } \\
\text { content, } \\
\%\end{array}$} & \multirow{2}{*}{$\begin{array}{c}\text { Dry } \\
\text { gluten } \\
\text { content, } \\
\%\end{array}$} & \multicolumn{3}{|c|}{ Gluten quality indicators } \\
\hline & & & & $\begin{array}{c}\text { Extensibility, } \\
\text { cm }\end{array}$ & $\begin{array}{c}\text { Elasticity, } \\
\text { FDM }\end{array}$ & $\begin{array}{c}\text { Hydratation } \\
\text { capacity, } \\
\%\end{array}$ \\
\hline \multicolumn{2}{|c|}{$\begin{array}{l}\text { Control (top-grade wheat } \\
\text { flour) }\end{array}$} & 28,5 & 9,9 & 19 & 81,6 & 188,5 \\
\hline \multirow{3}{*}{$\begin{array}{l}\text { Top-grade } \\
\text { wheat flour, } \\
\text { wheat fibre }\end{array}$} & 15 & 26,7 & 9,4 & 17 & 66,9 & 184,1 \\
\hline & 20 & 25,5 & 9,0 & 16 & 64,6 & 181,3 \\
\hline & 25 & 24,2 & 8,8 & 13 & 62,8 & 176,8 \\
\hline \multirow{3}{*}{$\begin{array}{l}\text { Top-grade } \\
\text { wheat flour, } \\
\text { apple fibre }\end{array}$} & 15 & 25,3 & 8,6 & 16 & 69,9 & 183,1 \\
\hline & 20 & 24,1 & 8,3 & 14 & 65,4 & 182,6 \\
\hline & 25 & 21,4 & 7,7 & 12 & 61,2 & 177,8 \\
\hline \multirow{3}{*}{$\begin{array}{l}\text { Top-grade } \\
\text { wheat flour, } \\
\text { cocoa fibre }\end{array}$} & 15 & 23,3 & 8,2 & 17 & 74,7 & 185,7 \\
\hline & 20 & 21,8 & 7,9 & 16 & 73,5 & 184,3 \\
\hline & 25 & 19,9 & 7,1 & 12 & 70,8 & 180,1 \\
\hline
\end{tabular}


The obtained data show (Table 1) that adding fibre results reduces the number of wet and dry gluten. Thus, when replacing $20 \%$ wheat flour with fibre, the content of wet gluten reduces to $10.5 \%$ for $\mathrm{WF}, 15.4 \%$ for $\mathrm{AF}$ and $23.5 \%$ for $\mathrm{CF}$ and dry gluten to $-9.0 \%, 16.2 \%$ and $20.2 \%$ respectively compared to the control.

With increasing dosage of fibre in the test range, gluten strengthening happens. It becomes more elastic and has lower extensibility. Strengthening effect of the concentrates is connected with high hydrophilic constituents of their polysaccharide complexes that have a significant dehydrating impact on the dough biopolymers. It is evidenced by the reduction in hydration capacity of dough gluten with the raw material, namely $2.3-6.2 \%$ when added WF, 2.8-5.6\% with the addition of AF and 1.4-4.5\% when added CF compared to hydration of gluten washed from the dough without it.

It should be noted that the formation of the strong fibrinous frame might cause the excessive compaction of the dough structure through the considerable resistance of elastic gluten to the expansion of the air bubbles due to temperature rise while baking and getting not enough loosened crumb of the baked semi-finished biscuits and reduce their volume and porosity [4].

A series of measurements with the help of farinograph was done to establish the impact of fibre on the elastic properties of the dough (Table 2). While kneading, water was added in the amount necessary to achieve the level of consistency of the dough 500 units of the device. The dough was kneaded for 15 minutes.

Indicator values of the dough elastic properties using farinograph

Table 2

\begin{tabular}{|c|c|c|c|c|c|c|}
\hline \multirow[b]{2}{*}{$\begin{array}{l}\text { Dough } \\
\text { samples }\end{array}$} & \multirow[b]{2}{*}{$\begin{array}{c}\text { Replacement } \\
\text { of dough } \\
\text { into fibre, \% }\end{array}$} & \multicolumn{5}{|c|}{ Indicator Values } \\
\hline & & $\begin{array}{c}\text { Time of } \\
\text { formation, } \\
\text { min. }\end{array}$ & $\begin{array}{l}\text { Stability, } \\
\text { min. }\end{array}$ & $\begin{array}{c}\text { Dilution, } \\
\text { units }\end{array}$ & $\begin{array}{l}\text { Elasticity, } \\
\text { units }\end{array}$ & $\begin{array}{c}\text { Water } \\
\text { absorbing } \\
\text { ability, \% }\end{array}$ \\
\hline \multicolumn{2}{|c|}{$\begin{array}{l}\text { Control (top-grade wheat } \\
\text { flour) }\end{array}$} & 2,0 & 1,0 & 80,0 & 52,0 & 56,0 \\
\hline \multirow{3}{*}{$\begin{array}{l}\text { Top-grade } \\
\text { wheat flour, } \\
\text { wheat fibre }\end{array}$} & 15 & 2,0 & 0,5 & 100,0 & 44,0 & 63,0 \\
\hline & 20 & 2,5 & 0,5 & 110,0 & 42,0 & 66,0 \\
\hline & 25 & 3,0 & 0,5 & 120,0 & 39,0 & 69,0 \\
\hline \multirow{3}{*}{$\begin{array}{l}\text { Top-grade } \\
\text { wheat flour, } \\
\text { apple fibre }\end{array}$} & 15 & 1,0 & 0,0 & 90,0 & 48,0 & 59,0 \\
\hline & 20 & 1,5 & 0,0 & 100,0 & 45,0 & 63,0 \\
\hline & 25 & 2,0 & 0,0 & 110,0 & 43,0 & 65,0 \\
\hline \multirow{3}{*}{$\begin{array}{l}\text { Top-grade } \\
\text { wheat flour, } \\
\text { cocoa fibre }\end{array}$} & 15 & 1,5 & 0,0 & 80,0 & 46,0 & 57,0 \\
\hline & 20 & 2,0 & 0,0 & 90,0 & 45,0 & 60,0 \\
\hline & 25 & 2,0 & 0,0 & 100,0 & 43,0 & 63,0 \\
\hline
\end{tabular}

A result of research (Table 2) established that fibre increases the degree of water binding by the dough on average by $12.5-23.2 \%$, due to the ability of the polysaccharide complex of DF to bind and retain water, creating a competition for the major biopolymers of the dough, especially for gluten proteins and starch in the absorption of water. Intensive water binding by fibre reduces the moisture in the dough proteins and quantity of gluten, which is obviously associated with more severe dehydrating effect on it, but at the same time the fibre does not provide dough with appropriate elastic properties, which would do necessary physical resistance to the working body of farinograph. 
It should be noted that the introduction of the investigated concentrates leads to hardening of the dough compared to the control sample by $11.5-17.3 \%$ for CF and $7.7-$ $17.3 \%$ for AF. The most noticeable decrease of this indicator is typical for the dough with WF, namely by $15.4-25 \%$. The loss of elasticity of the dough is apparently associated with the reduced proportion of gluten in the dough and a significant dehydrating impact of fibre on gluten proteins. The lack of a well-formed elastic fibrinous frame leads to the loss of elasticity, which correlates with data on the quality of gluten [5].

Confirmation of the results is the definition of structural-and-mechanical properties of the dough with fibre on alveograph, which showed that when adding the studied material in an amount of $15-25 \%$ to the weight of flour, the dough loses its elasticity and acquires plasticity.

Rheological properties of the dough depend largely on the state of the proteinproteinase complex of flour and define the quality indicators of the flour confectionery products. Proteins of wheat flour can form resilient hydrated gel, which significantly affects the structural-and-mechanical properties of the dough. The following quality indicators of the dough were determined on alveograph: elasticity $(\mathrm{P}, \mathrm{mm})$ that corresponds to elastic deformation of the dough; extensibility $(\mathrm{L}, \mathrm{mm})$ that is a maximum volume of the air that can keep the dough bubbles; amount of energy spent on inflating a bubble until its break or deformation work $\left(\mathrm{W}, 10^{-4} \mathrm{~J}\right)$; and ratio of $\mathrm{P} / \mathrm{L}$ (Table 3 ).

Table 3

\section{Alveograph indicators of the biscuit dough}

\begin{tabular}{|l|c|c|c|c|c|}
\hline \multicolumn{1}{|c|}{$\begin{array}{c}\text { Dough } \\
\text { samples }\end{array}$} & $\begin{array}{c}\text { The replace- } \\
\text { ment of } \\
\text { dough into } \\
\text { fibre, \% }\end{array}$ & $\begin{array}{c}\text { Elasticity } \\
\mathbf{( P )}, \text { units }\end{array}$ & $\begin{array}{c}\text { Extensi- } \\
\text { bility (L), } \\
\text { mm }\end{array}$ & $\begin{array}{c}\text { Ratio } \\
\text { of P/L }\end{array}$ & $\begin{array}{c}\text { Deformation } \\
\text { work, (flour } \\
\text { strength) J·10-4 }\end{array}$ \\
\hline \multirow{2}{*}{$\begin{array}{l}\text { Control (top-grade wheat } \\
\text { flour) }\end{array}$} & 83 & 84 & 0,99 & 203 \\
\hline \multirow{2}{*}{$\begin{array}{l}\text { Top-grade } \\
\text { wheat flour, } \\
\text { wheat fibre }\end{array}$} & 15 & 138 & 44 & 3,13 & 273 \\
\cline { 2 - 6 } & 20 & 149 & 34 & 4,38 & 287 \\
\hline \multirow{2}{*}{$\begin{array}{l}\text { Top-grade } \\
\text { wheat flour, } \\
\text { apple fibre }\end{array}$} & 25 & 166 & 27 & 6,14 & 302 \\
\cline { 2 - 6 } & 15 & 124 & 69 & 1,79 & 251 \\
\hline \multirow{2}{*}{$\begin{array}{l}\text { Top-grade } \\
\text { wheat flour, } \\
\text { cocoa fibre }\end{array}$} & 20 & 138 & 56 & 2,46 & 260 \\
\cline { 2 - 6 } & 25 & 153 & 47 & 3,25 & 286 \\
\hline
\end{tabular}

The obtained data (Table 3) indicate that the introduction of fibre in an amount of 15$25 \%$ by flour weight compared with the control increases the elasticity of the dough by $1,2-$ 2 times and reduces the extensibility by $1.3-3$ times. The extensibility decreases mostly when adding WF, namely by $45.6-65.8 \%$. The received data can be explained by a high content of polysaccharides in the fibre, which does not allow to form elastic fibrinous frame and increase the viscosity of the dough, which increases its resistance when stretching on the alveograph table, that is fixed obviously by a device as a growth of elasticity P. As evidence of this it can be observed a growth of deformation work $\mathrm{W}$, which is spent on stretching the samples of the dough and characterizes the strength of the flour. 
The ratio of $\mathrm{P} / \mathrm{L}$, which characterizes a balance between indicators of the physical properties of the dough, rises. This is because the elastic properties of the dough decrease at a slower pace than extensibility.

Previous studies and analysis of the chemical composition of the DF concentrates indicate that it contains biologically active substances, among which the most important place is occupied by pectin, fibre, vitamins and minerals. Considering the difference between the chemical composition of the studied material, it is appropriate to examine its impact on the gelatinization of the starch of the wheat flour. The data are shown in Table 4 .

The study of the process of the starch gelatinization was carried out using Brabender amylograph. The device in a graphic form registered changes of the viscosity of water-flour suspension at a constant temperature rise characterizing the changes of the starch because of its gelatinization with the presence of the flour enzymes [6].

\section{Gelatinization process indicators of the control sample (C) and samples with added 15,20 and $25 \%$ by flour weight}

Table 4

\begin{tabular}{|c|c|c|c|c|c|c|c|c|c|c|c|c|}
\hline & \multicolumn{10}{|c|}{ Amount of fibre, \% } \\
\hline & C & 15 & 20 & 25 & C & 15 & 20 & 25 & C & 15 & 20 & 25 \\
\hline $\begin{array}{c}\text { Temperature } \\
\text { of the } \\
\text { beginning of } \\
\text { gelatinization }\end{array}$ & 52 & 44 & 42 & 40 & 52 & 46 & 44,5 & 42 & 52 & 48 & 46 & 43 \\
\hline $\begin{array}{c}\text { Maximal } \\
\text { viscosity }\end{array}$ & 265 & 280 & 290 & 300 & 265 & 265 & 275 & 280 & 265 & 270 & 280 & 290 \\
\hline
\end{tabular}

* C - control sample

Table 4 shows that with the introduction of fibre in an amount of $15-25 \%$ by weight of flour, the initial temperature of gelatinization reduces on average by $7.6-23.2 \%$. It should be noted that the change in temperature of the starch gelatinization is an important indicator that characterizes the process of its retrogradation. It is known that the lower the temperature of the starch gelatinization is, the slower the flour products firm. This suggests that the products from the biscuit dough with the addition of the studied concentrates will maintain freshness longer during storage [11].

The results show that the introduction of fibre affects the viscosity of the starch paste. The addition of fibre to the wheat flour in an amount of $15-25 \%$ of its weight contributes to the viscosity of the suspension by $1.1-13.2 \%$ respectively. This is because firstly, fibre contains a large amount of the polysaccharides that can bind water and thicken a system, increasing its viscosity. Secondly, they contain a significant amount of organic acids and polyphenolic compounds, which contributes to the inactivation of the amylase and, consequently, a smaller dilution of water-flour suspension when heated [12].

Data analysis suggests that the introduction of the indicated fibres in an amount of 15 to $25 \%$ by weight of top-grade flour reduces the quantity of the washed raw, and dry gluten. Thus, extensibility reduces and accordingly elasticity and hydratation capacity. As shown in Table 1-3, the introduction of wheat fibre strengthens gluten, which is a negative factor in relation to the biscuit dough, so it is appropriate to provide the introduction of surface- 
active surfactants (SAS) that will weaken it and thus contribute to obtain finished products with greater porosity and specific volume.

SAS - chemical compounds, concentrating on the interface, causing reduction of the surface tension. One of the most common surfactants, which gained recognition in the technology of flour confectionery products is non-ionic. They are usually compatible with other classes of surfactants, are added to the raw materials in small quantities and are relatively inexpensive. Non-ionic surfactants enable mostly to form an even thin-walled structure of the crumb of FCP that is able to be fresh for a long time and create a relaxative effect on gluten of the dough.

It is suggested to use non-ionic surfactants in the capacity of SAS for the semi-finished biscuits - a mixture of the emulsifiers «Grindsted Cake» produced by Danisco (Denmark) [11] consisting of propylene glycol ester and fatty acids (E 477), mono- and diglycerides of fatty acids (E 471), lactic acid sodium stearate (E 481).

The next stage of the research was to determine an effect of fibre in an amount of $20 \%$ (optimal dosage) by weight of flour with the addition of a mixture of the emulsifiers «Grindsted Cake» on the quality of gluten of top-grade wheat flour (Table 5).

Table 5

Emulsifiers «Grindsted Cake» effect on the fibre quality indicators

\begin{tabular}{|l|c|c|}
\hline \multicolumn{1}{|c|}{ Dough samples } & Extensibility, cm & Elasticity, FDM \\
\hline Top-grade wheat flour & 19,0 & 81,6 \\
\hline Top-grade wheat flour, wheat fibre - 20\% & 16,0 & 64,6 \\
\hline $\begin{array}{l}\text { Top-grade wheat flour, wheat fibre - 20\% } \\
+ \text { «Grindsted Cake» }\end{array}$ & 19,5 & 83,7 \\
\hline Top-grade wheat flour, apple fibre - 20\% & 14,0 & 65,4 \\
\hline $\begin{array}{l}\text { Top-grade wheat flour, apple fibre - 20\% } \\
+ \text { «Grindsted Cake» }\end{array}$ & 19,0 & 85,8 \\
\hline Top-grade wheat flour, cocoa fibre - 20\% & 16,0 & 73,5 \\
\hline $\begin{array}{l}\text { Top-grade wheat flour, cocoa fibre - 20\% } \\
+ \text { «Grindsted Cake» }\end{array}$ & 19,5 & 87,2 \\
\hline
\end{tabular}

Table 5 shows that the introduced emulsifier allows to reduce gluten, improve its extensibility on average by $2.6 \%$ and elasticity by $2.6-6.8 \%$. Therefore, it can be predicted that the finished products with the addition of «Grindsted Cake» will have larger volume, better porosity and structure [13].

Baking tests were carried out to determine the effect of fibre on the quality indicators of the finished semi-finished biscuits and their quality indicators were determined, in particular - the specific volume, porosity, lifting coefficient and baking loss (Table 6).

Table 6 shows that the addition of fibre degrades the quality of the baked semi-finished products by all indicators except baking loss whose value is decreased with increasing dosage of fibre, apparently due to its high water-absorbing and water-retaining ability.

Porosity of the semi-finished biscuits with the introduction of fibre compared to the control sample is lower by $2.3-9.6 \%$ for $\mathrm{WF}, 1.4-6.6 \%$ for $\mathrm{AF}$ and $0.5-1.8 \%$ for $\mathrm{CF}$ respectively. Specific volume and lifting coefficient also deteriorate, which can be explained by high ability of fibre to absorb and retain water and thereby create a competition for other dough biopolymers. 
Quality indicators of the semi-finished biscuits with added fibre

Table 6

\begin{tabular}{|l|c|c|c|c|c|}
\hline \multicolumn{1}{|c|}{$\begin{array}{c}\text { Dough } \\
\text { samples }\end{array}$} & $\begin{array}{c}\text { The replace- } \\
\text { ment of dough } \\
\text { into fibre, } \%\end{array}$ & $\begin{array}{c}\text { Specific } \\
\text { volume } \\
\mathbf{c m}^{\mathbf{3}} \mathbf{g}\end{array}$ & Porosity, \% & $\begin{array}{c}\text { Lifting } \\
\text { coeffi- } \\
\text { cient, units }\end{array}$ & $\begin{array}{c}\text { Baking } \\
\text { loss, \%o }\end{array}$ \\
\hline Control & & 2,46 & 68,8 & 1,83 & 9,9 \\
\hline \multirow{2}{*}{$\begin{array}{l}\text { Top-grade } \\
\text { wheat flour, } \\
\text { wheat fibre }\end{array}$} & 15 & 2,39 & 67,2 & 1,70 & 8,4 \\
\cline { 2 - 6 } & 20 & 2,35 & 65,5 & 1,65 & 7,3 \\
\hline \multirow{2}{*}{$\begin{array}{l}\text { Top-grade } \\
\text { wheat flour, } \\
\text { apple fibre }\end{array}$} & 25 & 2,28 & 62,1 & 1,59 & 6,9 \\
\cline { 2 - 6 } & 15 & 2,44 & 67,8 & 1,76 & 9,0 \\
\hline \multirow{2}{*}{$\begin{array}{l}\text { Top-grade } \\
\text { wheat flour, } \\
\text { cocoa fibre }\end{array}$} & 20 & 2,40 & 66,4 & 1,72 & 8,2 \\
\cline { 2 - 6 } & 25 & 2,36 & 64,2 & 1,66 & 7,7 \\
\cline { 2 - 6 } & 15 & 2,45 & 68,4 & 1,80 & 9,2 \\
\hline
\end{tabular}

Since the previous studies determined that CF has the least water-absorbing ability, the finished products when added it have structural-and-mechanical indicators of the quality that are close to the control sample.

Based on the obtained data above about weakening gluten of wheat flour when adding the emulsifier "Grindsted Cake» (Table 5), it was decided to determine its impact on the quality of the finished semi-finished biscuit with the addition of the DF concentrates (Table 7).

Table 7

Quality indicators of the semi-finished biscuits with added fibre and a mixture of the emulsifiers «Grindsted Cake»

\begin{tabular}{|l|c|c|c|c|c|}
\hline \multicolumn{1}{|c|}{ Samples } & $\begin{array}{c}\text { The } \\
\text { replacement } \\
\text { of dough } \\
\text { into fibre, } \\
\text { \% }\end{array}$ & $\begin{array}{c}\text { Specific } \\
\text { volume } \\
\mathbf{c m}^{\mathbf{3}} / \mathbf{g}\end{array}$ & Porosity,\% & $\begin{array}{c}\text { Lifting } \\
\text { coefficient, } \\
\text { units }\end{array}$ & $\begin{array}{c}\text { Baking } \\
\text { loss, \% }\end{array}$ \\
\hline Control & 15 & 2,46 & 68,8 & 1,83 & 9,9 \\
\hline $\begin{array}{l}\text { Top-grade wheat flour, } \\
\text { wheat fibre }\end{array}$ & 20 & 2,44 & 68,4 & 1,81 & 8,4 \\
\cline { 2 - 6 } & 25 & 2,41 & 68,0 & 1,78 & 7,3 \\
\hline \multirow{2}{*}{$\begin{array}{l}\text { Top-grade wheat flour, } \\
\text { apple fibre }\end{array}$} & 15 & 2,58 & 67,2 & 1,71 & 6,9 \\
\cline { 2 - 6 } & 20 & 2,52 & 69,1 & 1,86 & 9,0 \\
\hline $\begin{array}{l}\text { Top-grade wheat flour, } \\
\text { cocoa fibre }\end{array}$ & 25 & 2,44 & 68,2 & 1,84 & 8,2 \\
\cline { 2 - 6 } & 15 & 2,62 & 72,3 & 1,89 & 7,7 \\
\hline
\end{tabular}

It can be concluded from Table 7 that adding a mixture of the emulsifiers «Grindsted 


\section{— Food Technologies}

Cake» leads to increased porosity, specific volume and lifting coefficient of the finished product with the addition of $\mathrm{WF}, \mathrm{AF}$, and $\mathrm{CF}$, thus, allowing to bring the quality indicators of the semi-finished biscuits to that of a control, or surpass them. In particular, for the samples with the replacement of flour with AF and CF in the amount of $20 \%$ a specific volume of the finished products increased by $2.4 \%$ and $5.2 \%$, porosity by $1.0 \%$ and $2.8 \%$, and lifting coefficient by $0.5 \%$ and $1 \%$ respectively compared with the control.

The studied quality indicators approach the controls for the sample with the introduction of WF. Thus, the specific volume is lower by $0.8-4.0 \%$, porosity $-0.6-2.3 \%$, and lifting coefficient $-1-2.7 \%$ respectively.

Therefore, it can be concluded that in order to improve the quality of the semi-finished biscuits with added fibre it is appropriate to introduce the emulsifier «Grindsted Cake».

\section{Conclusion}

Thus, adding 15-25\% fibre to the weight of flour reduces the amount of wet gluten by $10.5 \%$ for $\mathrm{WF}, 15.4 \%$ for $\mathrm{AF}$ and $23.5 \%$ for $\mathrm{CF}$ and dry gluten respectively by $9.0 \%$, $16.2 \%$, and $20.2 \%$. There is a strengthening effect of fibre on the fibrinous frame, which can be associated with high hydrophilic constituents of their polysaccharide complexes that have a significant dehydrating impact on the dough biopolymers.

It is researched that the presence of fibre promotes water absorption ability and formation time of the dough and reduces its stability. It is found that fibre increases the degree of water binding by the dough on average by $12.5-23.2 \%$, due to the ability of polysaccharide complex to bind and retain water. It should be noted that the introduction of the investigated concentrates leads to hardening of the dough by $1.7-23.2 \%$ compared to the control sample. The most noticeable decrease of this indicator is typical for the dough with WF.

The results of the study on alveograph indicate that the introduction of fibre in the amount of $15-25 \%$ of flour weight compared with the control increases the dough elasticity by $1,2-2$ and reduces the extensibility by $1.3-3$ times. The obtained data can be explained by a high content of the polysaccharides in the raw materials, which do not allow to form the elastic fibrinous frame and increase the viscosity of the dough.

It is found that initial temperature for gelatinization of the water-flour mixture with added fibre reduces on average by $7.6-23.2 \%$. The study material affects the viscosity of the starch paste and contributes to its increase by $1.1-13.2 \%$, which can be explained by a large number of polysaccharides in its structure that can bind water and thicken the system increasing its viscosity.

It is determined that the introduction of fibre together with a mixture of emulsifiers "Grindsted Cake» to the dough increases its extensibility on average by $2.6 \%$ and elasticity by $2.6-6.8 \%$, which will obviously have a positive impact on the quality of finished products.

The obtained data allows to assert that structural-and-mechanical indicators of the quality of semi-finished biscuits with the introduction of dietary fibre concentrates compared with the control reduce, in particular, the porosity by $2.3-9.6 \%$ for WF, $1.4 \% \ldots$ 6.6 for $\mathrm{AF}$ and by $0.5-1.8 \%$ for $\mathrm{CF}$ respectively. Adding a mixture of the emulsifiers "Grindsted Cake» leads to increased porosity, specific volume and lifting coefficient of the finished products with the addition of WF, AF, and CF, thus allowing to bring the quality indicators of the semi-finished products to that of a control or surpass them. 


\section{References}

1. Samuel F. (2012), Nutrient and Antinutrient content of soy- enriched tapioca, Food and Nutrition Sciences, 23(3), pp. 23-32.

2. Majzoobi M. (2013), Effect of different Levels and Particle Sizes of Wheat bran on the quality of flat bread, Garg Sci Tech Glass, 5(1), pp. 115-123.

3. Bruno Ricardo De Castro Leite Júnior, Marcelo Cristianini (2016), Determination of the influence of High pressure processing on calf rennet using response surface methodology: Effects on milkcoagulation, Food Science and Technology, 65, pp. 10 17.

4. Zapototska O. V. (2012), Vukorustannya harchovuh volokon pru vurobnutstvi rusovogo korpusu dlya koekstryziynuh prodyktiv, Ukrainian Food Journal, 3, pp. 27 30 .

5. Steigman A. (2008) All Dietary Fiber is fundamentally functional, Cereal foods world, 48, pp. 128-132.

6. Djuruk N.P., Kovalchyk M.P. (2008), Novi vudu hlibobulochnih vurobiv pidvuschenoyi harchovoi tsinnosti, Hlebopekarskoe i konditerskoe delo, 1, pp. 18-19.

7. Bonsdorff M., Rantanen T., Sipila S. (2011), Birth size and childhood growth as determinants of physical function in ginolderage: the Helsinki birth cohort study, Am. J. Epidemiol, 174(12), pp. 1336-1344.

8. Sabanis D. (2011), Effect of hydrocolloids on selected properties of gluten-free dough and bread, Food Scienceand Technology, 17(4), pp. 91-100.

9. Vasilica N. (2011), Strong flour improvement using maltflour, Journal of Agroalimentary Processesand Technologies, 15(2), pp. 242-244.

10. Svek I. (2009) Image Data of Crumb Structure of Bread from Flour of Czech Spring Wheat Cultivars, Czech Journal of Food Technologies, № 22(4), pp. 133-142.

11. Sidorova L.N., Glovenko M.V. (2008), Pischevie volokna v proizvodstve konditerskih isdeliy, Konditerskoe proszvodstvo, 2, pp.18-20.

12. Samohvalova O.V., Kasabova K.R. (2011), Zbagachennya mafiniv harchovumi voloknami, Naykovi pratsi ONAHT, 40(1), pp. 161-163.

13. Brennan C. S., Tan C. K. (2014), The pasting behavior and freeze-thaw stability of native starch and native-xanthat gym pastes, International Journal of food Scienceand Technology, 10(39), pp. 1017-1022. 